\title{
Sposób prowadzenia badań archeologiczno-architektonicznych, a możliwości wykorzystania ich wyników w procesie projektowym na przykładzie byłego Szpitala im. Babińskiego we Wrocławiu
}

\author{
Justyna Kleszcz ${ }^{1}$, Piotr Kmiecik ${ }^{2}$ \\ ${ }^{1}$ Katedra Architektury i Urbanistyki, Wydziat Budownictwa, Architektury i Inżynierii Środowiska, \\ Uniwersytet Zielonogórski, e-mail: j.kleszcz@aiu.uz.zgora.pl \\ 2Pracownia B2,Wroctaw,e-mail: p.kmiecik@pracowniab2.pl
}

Streszczenie: Niniejszy artykuł stanowi omówienie zagadnienia trybu i sposobu prowadzenia badań archeologiczno-architektonicznych ze szczególnym uwzględnieniem możliwości prawnych oraz analizę skutków (pozytywnych i negatywnych) wyboru poszczególnych form na sposób, w jaki prowadzone są prace projektowe oraz możliwości ekspozycji odsłoniętych reliktów. Zagadnienia te zostaną omówione głównie na przykładzie prac prowadzonych od 2015 roku na obszarze byłego szpitala im. Babińskiego przy placu Jana Pawła II we Wrocławiu przez zespół badawczy pod kierunkiem dr inż. arch. Piotra Kmiecika oraz dr Roberta Szweda, przy współudziale dr Czesława Lasoty. Teren byłego Szpitala był zdecydowanie jednym z najciekawszych pod względem archeologiczno-architektonicznym we Wrocławiu, jednocześnie jednak również jednym z najbardziej skomplikowanych. $\mathrm{Na}$ stopień skomplikowania miało wpływ nie tyle nagromadzenie warstw kulturowych i spodziewanych odkryć, a samo położenie oraz nawarstwienie ciągłych przekształceń obszaru, skutkujące gęstą zabudową, a także nagromadzeniem czynnych magistrali sieciowych o znaczeniu tranzytowym, ukształtowaniem powiązań komunikacyjnych w obrębie rozległego obszaru i ukształtowaniem zieleni objętej ochroną prawną. Jednoczesne wystąpienie tylu czynników spowodowało niemożliwość oszacowania zakresu i wielkości prowadzonych prac przed ich rozpoczęciem, wymusiło elastyczność oraz konieczność zaaranżowania badań z uwzględnieniem udziału ekip budowlanych w ich trakcie. Poziom komplikacji wymuszał także pewne modyfikacje w trybie prowadzonych prac, co ukazuje konieczność weryfikacji podejścia do restrykcyjnego podziału, oraz ukazuje szereg możliwości, jakie daje ściślejsza współpraca na linii architekt-archeolog-urząd konserwatora zabytków-budowa.

Słowa kluczowe: badania archeologiczno-architektoniczne, wytyczne projektowe, konserwator zabytków.

\section{Wstęp}

Przeprowadzenie badań archeologiczno-architektonicznych staje się elementem niezbędnym w każdej sytuacji, w której planowane są prace budowlane w obiekcie zabytkowym lub wokół niego, lub też w sytuacji, gdy istnieje uzasadnione podejrzenie, że relikty takie możemy odkryć. W takiej sytuacji stosuje się zapisy Ustawy o ochronie zabytków i opiece nad zabytkami [1], a w szczególności art. 31 ust. 1a. Z reguły największe emocje 
budzi fakt, że inwestor zamierzający przedsięwziąć te działania jest obowiązany, z zastrzeżeniem art. 82a ust. 1, pokryć koszty badań archeologicznych oraz ich dokumentacji, o ile ich przeprowadzenie jest niezbędne w celu ochrony zabytków. Zakres i rodzaj niezbędnych badań, zgodnie z art. 31 ust. 2 wspomnianej Ustawy jest inwestorowi narzucany poprzez ustalenia wojewódzkiego konserwatora zabytków w drodze decyzji. Ich maksymalny zakres jest jednak ograniczony do obszaru w jakim planowane są prace, lub jaki obejmuje planowana inwestycja. Egzemplarz dokumentacji z przeprowadzonych badań podlega po ich zakończeniu nieodpłatnemu przekazaniu wojewódzkiemu konserwatorowi zabytków, zgodnie $\mathrm{z}$ art. 31 ust. 3 Ustawy.

Sama procedura oraz związane z tym skutki prawne, budowlane i konserwatorskie została opisana na przykładzie prac prowadzonych na obszarze byłego Szpitala Wojewódzkiego im. J. Babińskiego we Wrocławiu.

\section{Analiza przypadku - były Szpital im. Babińskiego we Wroclawiu}

\subsection{Uwarunkowania terenowe}

Teren byłego szpitala im. Babińskiego przy pl. Jana Pawła II we Wrocławiu stanowi obszar o kształcie zbliżonym do wydłużonego trójkąta, ograniczonego od północy brzegiem Odry, od zachodu fosą miejską, od wschodu ulicami Wszystkich Świętych, Antoniego Cieszyńskiego i budynkiem Arsenału Mikołajskiego (Muzeum Miejskie Wrocławia). Jego łączna powierzchnia przekracza 2,5 ha (Rys. 1). Obsługa komunikacyjna możliwa jest jedynie od południa, przez bramę zlokalizowaną bezpośrednio przy placu Jana Pawła II, stanowiącym bardzo istotny węzeł komunikacyjny miasta oraz od północnego wschodu. Zespół obejmuje 13 budynków, ale także objęty ochroną zespół zieleni oraz podziemną infrastrukturę techniczną. W skład tej ostatniej wchodzi wykonana w 2006 roku magistrala wodociągowa, sieć energetyczna średniego napięcia i linie światłowodowe. Poza tymi elementami o znaczeniu ponadlokalnym, niemal cały obszar pokryty jest siecią przewodów wodnych, kanalizacyjnych, cieplnych i elektrycznych pierwotnie przeznaczonych do obsługi zespołu szpitalnego.

Zespół poszpitalny wystawiony został na sprzedaż w 2009 roku. Ostatecznie sprzedano go w roku 2014 [2], przy czym pierwotny zamysł inwestora obejmował wyburzenie większości istniejących tam obiektów. Ostatecznie przyjęta koncepcja zakłada wyburzenie jedynie jednego z nich oraz gruntowny remont i przebudowę pozostałych, a także budowę dwóch wolnostojących wielopoziomowych parkingów podziemnych.

W związku z tak zaplanowaną inwestycją konieczne stało się przeprowadzenie badań archeologiczno - architektonicznych zgodnie z zapisami Miejscowego Planu Zagospodarowania Przestrzennego (dalej MPZP) [3] i obowiązującymi przepisami prawa. Ze względu na przewidywane nagromadzenie zabytków ruchomych i nieruchomych, powierzchnię badanego terenu i stopień skomplikowania są to jedne z największych i najbardziej złożonych prac badawczych prowadzonych na terenie Wrocławia w ciągu ostatniego półwiecza. Stanowią jednocześnie doskonały pretekst do przeanalizowania mechanizmów i wzajemnych zależności zachodzących między poszczególnymi uczestnikami wspomnianego procesu, tj. głównym projektantem, wykonawcą, zespołem badawczym i instytucjami nadzorującymi ze specjalnym uwzględnieniem urzędu Wojewódzkiego Konserwatora Zabytków. 


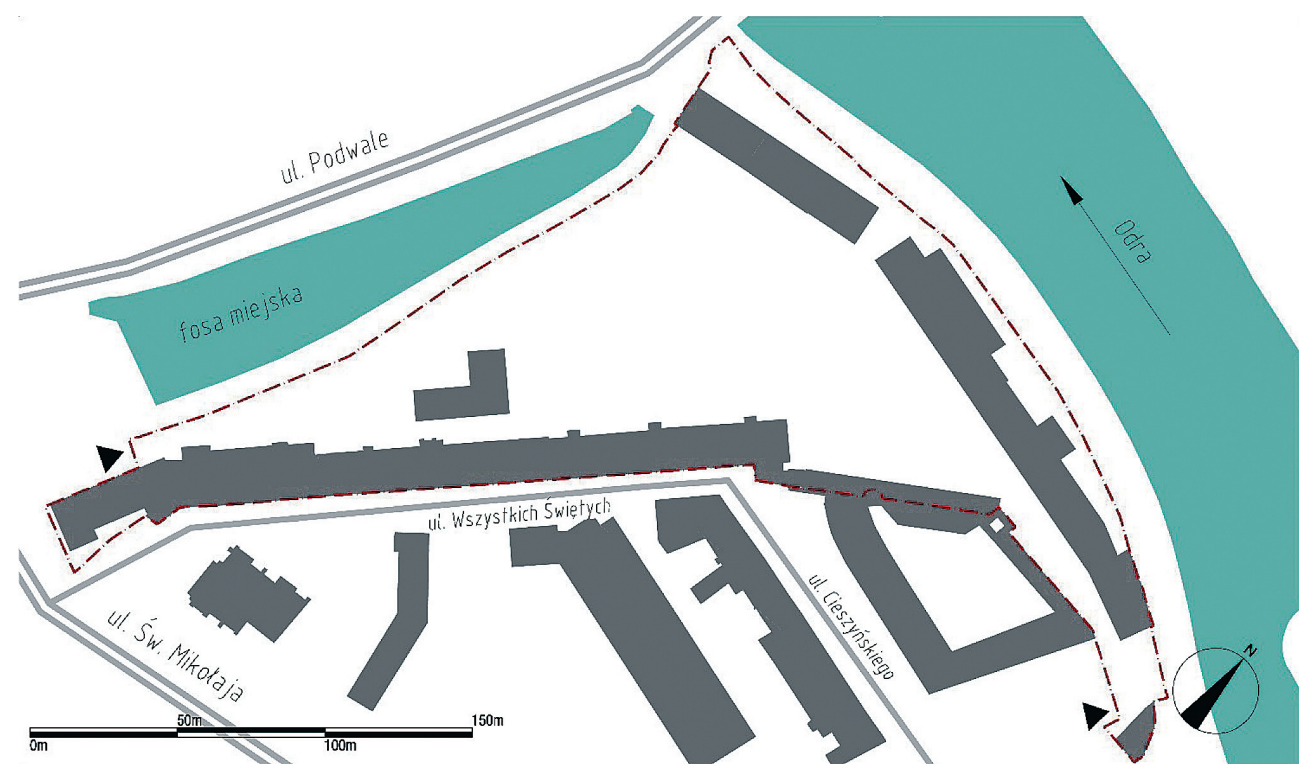

Rys. 1. Plan sytuacyjny z określonym obszarem badań archeologiczno-architektonicznych na terenie byłego Szpitala im. J.Babińskiego we Wrocławiu. Opracowanie: Autorzy

\subsection{Uwarunkowania konserwatorskie}

Teren byłego szpitala objęty jest MPZP [4], którego zapisy obejmują cały omawiany obszar strefą ochrony konserwatorskiej dla zespołu urbanistycznego oraz strefą ochrony konserwatorskiej dotyczącą zabytków archeologicznych (OW). Narzuca również w wypadku realizacji prac ziemnych na tym terenie przeprowadzenie wyprzedzających badań archeologiczno - architektonicznych i antropologicznych. Wprowadzona została także strefa ochrony konserwatorskiej (W) obejmująca znajdujące się na omawianym terenie zabytki archeologiczne średniowiecznego miasta, ze szczególnym uwzględnieniem bastionu kleszczowego i drugiej linii miejskich murów obronnych. Są to zapisy zgodne ze stanem wiedzy aktualnym na czas tworzenia Planu. Informacje o nich pochodziły jednak jedynie $\mathrm{z}$ analizy dostępnego materiału kartograficznego, były więc w wysokim stopniu nieprecyzyjne. Jedynym elementem umożliwiającym jakąkolwiek lokalizację wzmiankowanego bastionu były wyniki wyprzedzających badań archeologiczno-architektonicznych przeprowadzonych w 2012 roku przy realizacji inwestycji dotyczącej magistrali wodociągowej. W ich trakcie zlokalizowano niewielkie fragmenty zabytku, jednak ze względu na liniowy charakter niemożliwe było ani określenie jego wielkości, ani też precyzyjnego położenia. Dokładne dane posiadane przez projektantów przy przystępowaniu do tworzenia koncepcji adaptacji obszaru Szpitala dotyczyły więc jedynie istniejącego zagospodarowania terenu. Wiedza ta ograniczała się właściwie do zapisów zawartych w kilku publikacjach naukowych wzmiankujących jego historię oraz danych zebranych przez Urząd Konserwatorski jako dokumentacji wpisu do ewidencji i rejestru zabytków. W ogromnym skrócie przedstawiało się to następująco:

Omawiany obszar graniczy bezpośrednio z Arsenałem Mikołajskim [5] i wchodzącym w jego skład fragmentem XIV-wiecznych murów miejskich. Poza wpisanym 
2 XII 2014 roku do rejestru zabytków zespołem szpitalnym¹, w skład którego wchodzi 7 budynków [7], oraz elementami rozpoznanymi w trakcie wstępnych wizji lokalnych, takimi jak fragment drugiej linii murów miejskich i relikt kazamaty św. Barbary, w trakcie badań spodziewano się odnaleźć także relikty umocnień bastejowych, bastionu kleszczowego, fragmentów umocnień fryderycjańskich, a także pierwszego budynku szpitala z XVI wieku. Dodatkowym utrudnieniem było odkrycie w trakcie badań reliktów, których istnienie nie było możliwe do przewidzenia na etapie przygotowywania prac ze względu na brak jakichkolwiek informacji źródłowych. Są to przede wszystkim fragmenty nieukończonego zamku z końca XIII w., a także fragmenty kamieniarskie zidentyfikowane jako romańskie detale architektoniczne pochodzące ze zburzonego w 1525 roku opactwa na Ołbinie [8].

\section{Czynniki warunkujące tryb prowadzenia badań, a przyjęte rozwiązania}

Podstawą prawną do przeprowadzenia badań archeologiczno - architektonicznych jest decyzja o pozwoleniu na prowadzenie badań archeologicznych wydana przez Urząd Wojewódzkiego Konserwatora Zabytków. Zarówno tryb jej uzyskania, jak i sposób przeprowadzenia prac reguluje Ustawa o ochronie zabytków i opiece nad zabytkami [9] i rozporządzenie w sprawie prowadzenia prac konserwatorskich [10]. W tym jednak szczególnym przypadku nie będą to jedynie akty prawne mające wpływ na przyjęty sposób prowadzenia badań i rozwiązania projektowo - wykonawcze. Ze względu na znajdujący się na terenie zespół zieleni równie istotna staje się także Ustawa o ochronie przyrody [11]. Z kolei zarówno wysoki stopień zabudowania terenu, jak i przebiegające przezeń liczne i będące częściowo w ciągłym użyciu sieci infrastruktury technicznej wymuszają zastosowanie ustawy Prawo budowlane [12], oraz rozporządzenia Ministra Infrastruktury w sprawie warunków technicznych, jakim powinny odpowiadać budynki i ich usytuowanie [13].

Ustawa o ochronie zabytków ani żadne inne akty prawne nie definiują w żaden sposób pojęcia wyprzedzających badań archeologiczno - architektonicznych (a takie właśnie pojęcie użyte zostało w MPZP). W powszechnym rozumieniu są to jednak badania przeprowadzone przed przystąpieniem do jakichkolwiek prac związanych z inwestycją, w tym projektowych. Innym rodzajem badań (również nie zdefiniowanym prawnie) są badania ratownicze - czyli takie, które są prowadzone w trakcie prac budowlanych i mają na celu przebadanie, dokumentację i podjęcie ewentualnej decyzji o zachowaniu i ekspozycji reliktów odkrytych w ich trakcie. Oba te pojęcia są stosowane w praktyce konserwatorskiej.

Badania archeologiczno - architektoniczne na terenie byłego szpitala rozpoczęte zostały wiosną 2015 roku przez zespół pod kierunkiem dr inż. arch. Piotra Kmiecika i dr Roberta

\footnotetext{
1 Budynki dawnego Szpitala Wszystkich Świętych, następnie Szpitala Wojewódzkiego im. J. Babińskiego, dz. nr 5/3 AM-25 obręb Stare Miasto obejmują wymienione poniżej obiekty i zostały wpisane do Rejestru w granicach murów obwodowych [6]:

1. budynek szpitalny fundacji Friebe Agath,

2. budynek szpitalny fundacji rodziny Lösch, z wyłączeniem aneksów dostawionych do elewacji północnej i zachodniej,

3. budynek szpitalny fundacji M. J. Pulvermacher, z wyłączeniem aneksów dostawionych do elewacji wschodniej, szybu windy i dobudówki zachodniej dostawionych do elewacji północnej,

4. budynek szpitalny dawnej Nowej Przychodni (dobudowa do budynku fundacji M. J. Pulvermacher), z wyłączeniem aneksu dostawionego do elewacji południowej,

5. główny budynek szpitalny,

6. budynek szpitalny Instytutu Patologii,

7. budynek szpitalny, dawne kazamaty.
} 
Szweda. W sytuacji idealnej należałoby założyć, że zgodnie ze sformułowaną wyżej definicją nakazane zapisem MPZP wyprzedzające badania archeologiczno - architektoniczne zostaną przeprowadzone przed przystąpieniem do prac projektowych, a ich wyniki posłużą jako wytyczne dla projektantów. W sytuacji realnej wynikł jednak cały szereg utrudnień.

Ze względu na wspomniane wcześniej uwarunkowania dotyczące obsługi komunikacyjnej zespołu, rozwiązanie tej kwestii stało się niezwykle istotne. Sprawna i możliwie bezkolizyjna obsługa komunikacyjna stała się kluczowa zarówno dla możliwości realizacji inwestycji jak i przeprowadzenia badań. Wymusiło to przyjęcie etapowego modelu prowadzenia badań archeologiczno-architektonicznych. Skomunikowanie terenu budowy jedynie przy pomocy dwóch wjazdów, z czego jeden przyłączał się bezpośrednio do ruchliwego wielopasmowego skrzyżowania przy Pl. Jana Pawła II, a drugi do ul. Cieszyńskiego o przekroju uniemożliwiającym wjazd ciężkiego sprzętu spowodowało konieczność wydzielenia wzajemnie niewykluczających się etapów prac i pełnej koordynacji prowadzonych działań badawczych i budowlanych.

Ze względu na występujące na terenie nawarstwienia historyczne sięgające XI wieku oraz związane z tym znaczne podniesienie terenu, odkrywanie wcześniejszych reliktów musiało być prowadzone wewnątrz istniejących budynków, często poniżej poziomu ich fundamentowania. Równocześnie dostęp do części odkrytych reliktów, których obecność była udokumentowana kwerendą archiwalną, możliwy był jedynie po wyburzeniu fragmentów istniejącej zabudowy, do czego niezbędny był plan wyburzeń opracowywany jako element planowanych prac i przeprowadzony pod kierunkiem kierownika robót wyburzeniowych. Większość odnajdowanych reliktów architektury wymagała wykonania wykopów głębokich, sięgających 7-8 m poniżej poziomu terenu. Przeprowadzenie tego typu prac obejmowało zakres ziemnych robót budowlanych wymagających projektu robót oraz zabezpieczenia skarp wykopu, co ze względów badawczych jest niedopuszczalne, gdyż uniemożliwia sporządzenie profili i określenie przebiegu nawarstwień kulturowych. Stanowi to więc konieczny do rozwiązania problem prawno-logiczny. Z tych głównie względów dla możliwości realizacji inwestycji podstawowym stało się przekwalifikowanie trybu prowadzenia badań z wyprzedzających na ratownicze, co umożliwiło jednoczesną, skoordynowaną i etapową pracę zespołu badaczy oraz ekip budowlanych. Jednocześnie doprowadziło to jednak do sytuacji, w której cały proces projektowy musiał odbyć się przed ich przeprowadzeniem, co z jednej strony wiązało się z koniecznością dokonywania zmian w realizowanym już projekcie przy każdym nowym odkryciu, z drugiej natomiast uniemożliwiało pełne wykorzystanie potencjału nowych, często rewolucyjnych odkryć archeologicznych i architektonicznych.

\section{Propozycje zmian w przepisach warunkujących prowadzenie prac badawczych w świetle przeprowadzonych badań}

Jak wykazała powyższa analiza, w warunkach dużych i skomplikowanych inwestycji prowadzonych na substancji zabytkowej dopuszczone w Polsce procedury mają pewne braki. Prowadzą one do sytuacji, w której wyniki badań pojawiają się zbyt późno aby móc stanowić wytyczne projektowe. W związku z tym działania podejmowane przez zespoły projektowe mają charakter ratunkowy i doraźny, co może prowadzić do zaprzepaszczenia ogromnego potencjału zabytkowych obiektów. Naczelną koniecznością w wypadku prowadzenia badań archeologiczno-architektonicznych w świetle analizowanego przypadku staje się usankcjonowanie obecności zespołu badawczego jako elementu procesu budowlanego w trakcie jego trwania. Opracowanie trybu prowadzenia badań, który uwzględniałby 
możliwość przeprowadzenia wyprzedzających badań archeologiczno-architektonicznych jako elementu procesu budowlanego zaraz po opracowaniu wstępnej, zaakceptowanej przez inwestora i urząd nadzoru budowlanego/ stosownego wydziału architektury (jeżeli będzie to wymagane dla danej inwestycji) koncepcji architektonicznej umożliwiającej weryfikację zakresu koniecznych do przeprowadzenia badań bez angażowania pełnego zespołu projektowego i bez wstępnej konieczności uzyskania wszystkich niezbędnych zgód/ zapewnień/ pozwoleń, jako wstępnego etapu prac budowlanych. Spowoduje to ograniczenie kosztów zarówno prowadzenia badań, jak i samego procesu projektowego oraz przywróci właściwą kolejność prowadzenia prac mających na celu realizację inwestycji i pełną ochronę zabytków oraz umożliwiające jak najpełniejsze wykorzystanie ich potencjału naukowego i poznawczego, tj. uzyskanie materiałów służących faktycznie jako wytyczne konserwatorskie do projektowania, nie ograniczając ich znaczenia jedynie do czynnika powodującego konieczność wprowadzania zmian do już istniejącej pełno branżowej dokumentacji projektowej.

W obecnej sytuacji prawnej polskich zabytków rzetelne wyniki badań są uzyskiwane w momencie, gdy ich uwzględnienie w projekcie jest kosztowne i kłopotliwe, co znacznie ogranicza potencjał wykorzystania obiektów zabytkowych i ich adaptacji do nowych funkcji z pełnym poszanowaniem ich wartości historycznej.

\section{Literatura}

[1] Ustawa z dnia 23 lipca 2003 r. o ochronie zabytków i opiece nad zabytkami (Dz. U. z 2014 r. poz. 1446, z późn. zm.).

[2] Kokoszkiewicz M. Konserwator ochroni zabytkowe budynki szpitala Babińskiego. Gazeta Wyborcza, Wrocław, 26.03.2014, http://wroclaw.wyborcza.pl/wroclaw/1,35771,15685435,Konserwator_ochroni_zabytkowe_budynki_szpitala_Babinskiego.html, dostęp 02.12.2017.

[3] Uchwała nr XXVIII/978/08 rady miejskiej Wrocławia z dnia 11 grudnia 2008 r. w sprawie uchwalenia miejscowego planu zagospodarowania przestrzennego zachodniej części obszaru Starego Miasta - rejon Arsenału i ul. św. Mikołaja.

[4] Uchwała nr XXVIII/978/08 rady miejskiej Wrocławia z dnia 11 grudnia 2008 r. w sprawie uchwalenia miejscowego planu zagospodarowania przestrzennego zachodniej części obszaru Starego Miasta - rejon Arsenału i ul. św. Mikołaja.

[5] Burak M. Arsenat wrocławski. Muzeum Miejskie Wrocławia, Wrocław, 2012.

[6] Rejestr zabytków Miasta Wrocławia. 16.11.2017, http://bip.um.wroc.pl/artykuly/204/zabytki-wroclawia, wpis nr A/5945/1-7, odczyt: 23.11.2017.

[7] Wójtowicz M. Dawny szpital Wszystkich Świętych. Muzeum Architektury we Wrocławiu, Wrocław, 2008.

[8] Kmiecik P., Szwed R. Wystrój kamieniarski opactwa na Ołbinie w świetle najnowszych odkryć archeologiczno-architektonicznych na terenie bytego szpitala im. Józefa Babińskiego we Wrocławiu, [w:] Od benedyktynów i premonstratensów do salezjanów. Dzieje kościoła i parafii św. Michała Archanioła na wrocławskim Otbinie. (ed. Wójcik M.). Wydawnictwo Uniwersytetu Wrocławskiego, Wrocław, w druku.

[9] Ustawa z dnia 23 lipca 2003 r. o ochronie zabytków i opiece nad zabytkami (Dz. U. z 2014 r. poz. 1446, z późn. zm.).

[10] Rozporządzenie Ministra Kultury i Dziedzictwa Narodowego z dnia 22 czerwca 2017 r. w sprawie prowadzenia prac konserwatorskich, prac restauratorskich i badań konserwatorskich przy zabytku wpisanym do rejestru zabytków albo na Listę Skarbów Dziedzictwa oraz robót budowlanych, badań architektonicznych i innych działań przy zabytku wpisanym do rejestru zabytków, a także badań archeologicznych i poszukiwań zabytków (Dz. U. z 2017 poz. 1265). 
[11] Ustawa z dnia 16 kwietnia 2004 o ochronie przyrody (Dz. U. 2004 r. nr 92 poz. 880, z późn. zm.).

[12] Ustawa z dnia 7 lipca 1994 r. Prawo budowlane (Dz. U. 2017 r. poz. 1332, 1529).

[13] Rozporządzenie Ministra Infrastruktury z dnia 12 kwietnia 2002 r. w sprawie warunków technicznych, jakim powinny odpowiadać budynki i ich usytuowanie (Dz. U. 2015 r. poz. 1422).

\title{
The method of conducting archaeological and architectural research, and the possibility of using their results in design process on the example of the former Babiński Regional Hospital in Wroclaw
}

\author{
Justyna Kleszcz ${ }^{1}$, Piotr Kmiecik² \\ ${ }^{1}$ Department of Architecture and Urban Planning, Faculty of Civil Engineering, Architecture and \\ Environmental Engineering, University of Zielona Góra, e-mail: j.kleszcz@aiu.uz.zgora.pl \\ 2Pracownia B2, Wroctaw,e-mail:p.kmiecik@pracowniab2.pl
}

\begin{abstract}
The paper discusses the issue of the mode and method of conducting archaeological and architectural research with particular emphasis on legal possibilities and analysis of potential effects (both: positive or negative) of the choice of individual forms on the way of carrying out the design works and the opportunity of displaying exposed relics. These issues will be discussed mainly on the example of excavations carried out since 2015 in the area of the former J. Babiński Regional Hospital at Jana Pawła II Square in Wrocław by a research team led by dr ing. arch. Piotr Kmiecik and dr Robert Szwed, with the participation of dr Czesław Lasota. The area of the former hospital was definitely one of the most interesting in terms of archeology and architecture in Wroclaw, but also one of the most complicated. The degree of complexity was influenced not so much by the accumulation of cultural layers and expected discoveries, but by the location and stratification of continuous historical transformations of the area, resulting in dense development, as well as in accumulation of active network buses of transit importance, which resulted in forming communication linkage within a vast area and the existence of urban greenery covered by legal protection. The simultaneous occurrence of many factors resulted in the inability to estimate scope and size of conducted works before their commencement, forced flexibility and the need of arranging excavations taking into account permanent participation of construction team during that time. The level of complexity also forced some modifications in the mode of research, which shows the need of verifying the approach towards restrictive division between different forms of architectural and archeological research and shows numbers of opportunities offered by closer cooperation between architect, archeologist, the office of monument conservation and the construction site.
\end{abstract}

Keywords: archaeological and architectural research, design guidelines, historic monuments conservator. 